\title{
Biomass Assessment of Floating Aquatic Plant Eichhornia crassipes - A Study in Batticaloa Lagoon, Sri Lanka using Sentinel 2A Satellite Images
}

\author{
P. J. E. Delina*, N. D. K. Dayawansa ${ }^{1}$ and R. P. De Silva ${ }^{1}$ \\ Postgraduate Institute of Agriculture \\ University of Peradeniya \\ Sri Lanka
}

\begin{abstract}
Batticaloa Lagoon is one of the estuaries in the country which is frequently affected by floating aquatic plants; mainly Eichhornia crassipes. The present study aimed to develop a relationship between field measured and satellite derived biomass that can satisfactorily estimate the spatial distribution of green and dry biomass of the floating aquatic plants in Batticaloa Lagoon. Cloud free six Sentinel-2A images were acquired for the period of March 2017 to February 2018. Real time field measurements of biomass of floating aquatic plants were obtained in 12 locations in two weeks interval. A buffer zone of $3 \mathrm{~km}$ was created around the lagoon to obtain Land Use/Land Cover (LULC) distribution to study the influence of surrounding LULC on floating aquatic plants. A number of band ratios and indices were developed using Sentinel-2A images to establish relationships with the field estimated biomass. The LULC analysis revealed that paddy was the abundant land use in the study area and the cultivation was highly seasonal which impacts the distribution of floating aquatic plants in dry and wet seasons. Among 21 tested band ratios and indices, normalized difference red edge index (NDREI, $\left.r^{2}=0.78\right)$ and band ratio $B 8 / B\left(r^{2}=0.67\right)$ for the green biomass and band ratio B3/B4 $\left(r^{2}=0.73\right)$ and NDREI-Narrow $\left(r^{2}=0.61\right)$ for the dry biomass in dry and wet season showed strong positive correlation with field biomass. The temporal distribution of the estimated biomass also confirmed the potential of Sentinel-2A images to be used as a source of data for monitoring of floating aquatic plants in the lagoon due to high spatial and spectral resolution of NIR and Red edge bands. These estimated biomass maps can be used to identify the locations which are affected by aquatic plants in order to take proper control measures.
\end{abstract}

Keywords: Aquatic plants, biomass, band ratios, indices, sentinel $2 \mathrm{~A}$

\section{INTRODUCTION}

Coastal and inland shallow aquatic ecosystems provide habitats for a wide range of macrophytes including floating, submerged and emergent aquatic plants. Recent studies and reports have revealed that both natural and artificial water bodies in Sri Lanka are infested with aquatic plants (Sobadini, 2006). Around 15 invasive plant species have been identified over the past few decades as responsible for filling of wetlands in Sri Lanka. Among them, Eichhornia crassipes, Pistia stratiotes and Salvinia molesta are widely distributed and create many damages to wetlands than other invasive species. Batticaloa lagoon is one of the

\footnotetext{
${ }^{1}$ Faculty of Agriculture, University of Peradeniya, Sri Lanka

* Corresponding author: evandel_foa@yahoo.com
}

This is an open-access article distributed under the terms of the Creative Commons Attribution License, which permits unrestricted use, distribution, and reproduction in any medium, provided the original author and source are credited. 
estuaries subjected to significant pollution with the spreading of invasive alien floating aquatic plant, the Water Hyacinth (Eichhornia crassipes)

Spreading of this invasive alien species is an indication of sedimentation and eutrophication of the lagoon as a result of degradation of the ecosystem due to unplanned development works in the lagoon area (IUCN and CEA, 2006). Vegetation on shallow aquatic system can be determined and monitored by field surveys and in situ measurements in terms of Biomass (BM) which is defined as "the mass per unit area of living plant material" (Downing and Andreson, 1985; Madsen, 1993). Several techniques have been used for biomass measurements including fresh weight, dry weight and carbon weight per unit area (Madsen, 1993). Although field estimation of aquatic plants provides reliable results, the methods are time consuming, labour intensive and cost inefficient, especially when the water bodies are with large surface areas. However, remote sensing can also provide reliable information about the spatial distribution of floating aquatic plants under good spatial and temporal coverage which can be effectively used for mapping based on their canopy spectral response (Villa et al., 2017). The launch of Sentinel-2A Multispectral Imager (Sentinel 2A- MSI) in 2015 opened up a great potential in lake remote sensing (Cho et al., 2008). The imagery with $10 \mathrm{~m}$, $20 \mathrm{~m}$ and $60 \mathrm{~m}$ spatial resolution gives an opportunity to study even small water bodies. The NIR and NIR narrow bands ( 8 and $8 \mathrm{a})$ red band (4) and red edge bands (5, 6 and 7$)$ provide the potential for estimating chlorophyll content of the vegetation (Cho et al., 2008; Ha et al., 2017; ESA, 2017). Table 1 presents the specific band designations of Sentinel 2A- MSI.

Table 1. Specific band designations of Sentinel 2A (MSI).

\begin{tabular}{lcc}
\hline \multicolumn{1}{c}{ Sentinel-2 Bands } & $\begin{array}{c}\text { Central Wavelength } \\
(\boldsymbol{\mu} \mathbf{m})\end{array}$ & $\begin{array}{c}\text { Resolution } \\
(\mathbf{m})\end{array}$ \\
\hline Band 1 - Coastal aerosol & 0.443 & 60 \\
Band 2 - Blue & 0.490 & 10 \\
Band 3 - Green & 0.560 & 10 \\
Band 4 - Red & 0.665 & 10 \\
Band 5 - Vegetation Red Edge & 0.705 & 20 \\
Band 6 - Vegetation Red Edge & 0.740 & 20 \\
Band 7 - Vegetation Red Edge & 0.783 & 20 \\
Band 8 - NIR & 0.842 & 10 \\
Band 8A - Narrow NIR & 0.865 & 20 \\
Band 9 - Water Vapour & 0.945 & 60 \\
Band 10 - SWIR - Cirrus & 1.375 & 60 \\
Band 11 - SWIR & 1.610 & 20 \\
Band 12 - SWIR & 2.190 & 20 \\
\hline \multicolumn{2}{c}{ (Source:https://earth.esa.int/web/sentinel/user-guides/sentinel-2- } \\
\multicolumn{2}{c}{ msi/resolutions/spatial) }
\end{tabular}

Simple band ratios and Vegetation indices are some of the remote sensing approaches which use spectral bands that are sensitive to plants to estimate biomass (Jensen, 2004; Ayanlade, 2017). Chlorophyll $a$ and $b$ in the plants show high absorption in blue and red regions while high reflectance in NIR region. The red edge band shows the maximum vegetation reflectance between red and NIR spectrum (Jensen, 2004). Studies show that these visible and NIR regions can be related with various biomass measurements of the plants. In the study of Toming et al. (2016) ratios developed from band 3 (Green - 560nm), band 4 (Red - $665 \mathrm{~nm}$ ) and band 6 (Red edge-740 $\mathrm{nm}$ ) in S2A were used to estimate the chlorophyll in the lakes. The 
findings from the study of Villa et al. (2017) present that the healthy water hyacinth showed a typical vegetation spectral reflectance pattern in the green reflectance peak at around 557 $\mathrm{nm}$, red absorption near 660-670 $\mathrm{nm}$ and the NIR peak above $730 \mathrm{~nm}$. The plants in flowering stage showed very distinct spectral reflectance pattern at blue and red compared to green, where the NIR reflectance was comparatively lower than that of vegetative stage. These ratios and indices can be used to correlate diverse plant characteristics such as vegetation cover, vegetation type, water content, field biomass and chlorophyll amount (Cho et al., 2008; Villa et al., 2017) in both aquatic and terrestrial vegetation.

Therefore, the objectives of the study were to develop relationships between field measured biomass and band ratios and indices derived using S2 satellite images to estimate biomass of Eichhornia crassipes present in Batticaloa lagoon and to develop maps of Green and Dry biomass distribution in dry and wet season

\section{MATERIALS AND METHODS}

\section{Study area}

Batticaloa lagoon is located in the Eastern Province of Sri Lanka between $7^{\circ} 24^{\prime}-7^{\circ} 46^{\prime} \mathrm{N}$ and $81^{\circ} 35^{\prime}-81^{\circ} 49^{\prime} \mathrm{E}$. The lagoon is about $56.8 \mathrm{~km}$ long along meridian axis and it varies widely $0.5 \mathrm{~km}$ to $4 \mathrm{~km}$. The Batticaloa estuary is the second largest brackish water system in Sri Lanka (Figure 1). Three distinct longitudinal zones could be recognized in this lagoon, the upper saline zone, the middle transitional zone with salinity fluctuations and the lower zone which is predominately with fresh water (JUGAS, 2010). The climate of the study area comprises a wet season during North-East monsoonal period (October to February) characterized by high mean precipitation $(1250 \pm 230 \mathrm{~mm})$ and prolong dry season during the South- West monsoonal period (March to September) marked by low mean precipitation (300 $\pm 23 \mathrm{~mm}$ ) (Punyawardena, 2010).

\section{Sampling and field measurements}

Green Biomass (GBM) can be used as an index to measure the activity of vegetation (Jensen, 2004). Standing macrophyte biomass can be estimated by harvesting of randomly placed samples of a known area (Downing and Andreson, 1985). A number of field visits were conducted initially to select the sampling points. Twelve sampling sites (Figure 1) were chosen from locations which are known for occurrence of floating aquatic plants (FAP) (Eichhornia crassipes) in the lagoon. Sampling plot of $30 \times 30 \mathrm{~m}$ was selected at each site. Measurements were done in triplicate at each point by randomly placing a $1 \mathrm{~m}^{2}$ wooden frame in the immediate vicinity of the sampling point. The coordinates of the field points were obtained using a handheld GPS (Gramin- eTrex 30) and later converted into point vector data layer for further processing. The sampling points were selected along the lagoon shore considering the presence of FAPs. Field data were collected in real time to coincide with the S2A images during the period of March 2017 to February 2018 in two weeks interval. The fresh weight of floating aquatic plants in each quadrant were weighed to obtain the GBM of the FAPs. According to Madsen (1993) all the plants in the quadrant dug manually together with roots, washed from debris and drained well and their fresh weight were calculated. Samples were sun dried to a constant weight to determine Dry Biomass (DBM), to the nearest $0.1 \mathrm{~g}$. According to Madsen (1993) the fresh and dry weight of whole plants are considered as 
the GBM and DBM of the aquatic plants. Weight of all plants within a quadrant was transformed to fresh wt $\left(\mathrm{kg} / \mathrm{m}^{2}\right)$ and dry wt $\left(\mathrm{g} / \mathrm{m}^{2}\right)$.

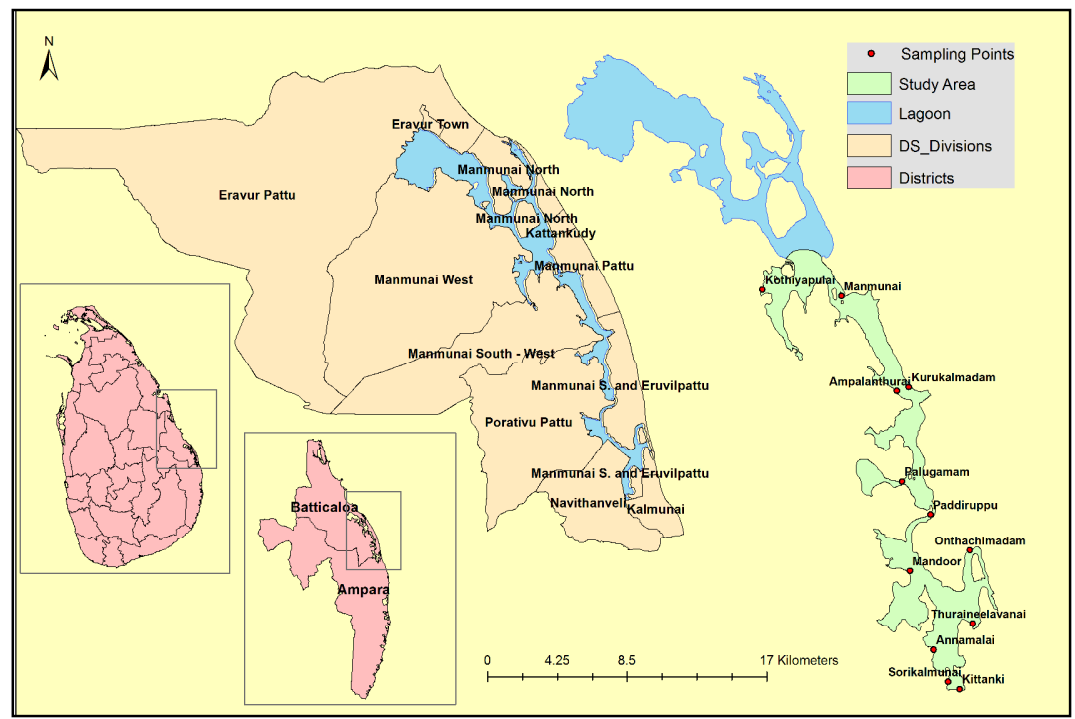

Figure 1. Study Area and Sampling Locations of Aquatic Plants at Batticaloa Lagoon.

\section{Image acquisition, pre- processing and classification}

Cloud free S2A (MSI) images with 10, 20 and $60 \mathrm{~m}$ resolution in UTM projection over Batticaloa Lagoon were acquired from the website of USGS (http://earthexplorer.usgs.gov/) (Table 2).

Table 2. Details of Sentinel 2A images over study area.

\begin{tabular}{ll}
\hline Season & Date of image acquisition \\
\hline Dry Season & $28^{\text {th }}$ May, $17^{\text {th }}$ June, $27^{\text {th }}$ July and $05^{\text {th }}$ September 2017 \\
Wet Season & $03^{\text {rd }}$ January and $24^{\text {th }}$ February 2018 \\
\hline
\end{tabular}

The multispectral images were used along with vector layer of Batticaloa Lagoon obtained from 1:50000 scale topographic maps of Survey Department, Sri Lanka to subset the study area. A buffer zone of $3 \mathrm{~km}$ was created around the lagoon to obtain the Land Use Land Cover (LULC) distribution around the lagoon area to study the influence on fluctuation of FAPs. Unsupervised classification is one of the techniques that have given better results in identifying the invasive alien plants in water bodies (Toming et al., 2016) along with the land use pattern. The images were classified using unsupervised classification into 36 classes Subsequently with the aid of field observations and high resolution Google Earth Images, LULC classes were identified and similar classed were merged to obtain 10 LULC classes which are dominant in the area.

\section{Development of remote sensing based indices and regression models}

All possible band ratios and vegetation indices based on the spectral regions that are sensitive to vegetation (Blue, Green, Red, NIR and Red edge) in estimation of biomass and chlorophyll content were evaluated in this study. Based on the studies by Cho et al. (2008) and Villa et al. 
(2017) simple ratios of B2/B3, B3/B2, B2/B4, B4/B2, B2/B8, B3/B8, B3/B4, B4/B3, B8/B4, $\mathrm{B} 3-\mathrm{B} 2, \mathrm{~B} 3-\mathrm{B} 4,(\mathrm{~B} 2+\mathrm{B} 3) / 2,(\mathrm{~B} 2+\mathrm{B} 4) / 2,(\mathrm{~B} 3+\mathrm{B} 4) / 2,(\mathrm{~B} 2-\mathrm{B} 3) / \mathrm{B} 3,(\mathrm{~B} 2-\mathrm{B} 4) /(\mathrm{B} 2+\mathrm{B} 4)$ and indices such as Normalized Difference Vegetation Index [NDVI (B8-B4)/(B8+B4)] (Rouse et al., 1974), Green Normalized Difference Vegetation Index [GNDVI (B8-B3)/(B8+B3)], Normalized Green Red Difference Index [NGRDI (B3-B4)/(B3+B4)] (Ayanlade, 2017), Normalized Difference Red Edge Index [NDREI (B8-B5)/(B8+B5) and NDREI_narrow (B8a-B5)/(B8a+B5)] (Cho et al., 2008; Toming et al., 2016) were used in this study. The SPSS version 16.0 was used for the correlation and regression analysis between field measurements and remote sensed based indices. The most suitable model which can predict biomass of Eichhornia crassipes were used to develop biomass maps of aquatic plants in Batticaloa Lagoon.

\section{RESULTS AND DISCUSSION}

\section{Seasonal distribution pattern of aquatic plants and LULC around the lagoon}

Sentinel-2A MSI sensor with $10 \mathrm{~m}$ spatial resolution provides a great benefit in the LULC classifications (Ha et al., 2017). It can be used to derive accurate and current spatial land cover information and monitor land cover changes over seasons in land and water bodies. The Sentinel 2A satellite images of $10 \mathrm{~m}$ spatial resolution for the period of 2017/2018 were used to identify the distribution of FAPs and LULC pattern around Batticaloa Lagoon. The classification of aquatic plants in the images of the S2A for the period of 2017/2018 revealed (Figure 2) that the distribution highly varies with the seasonal changes $\left(5-14 \mathrm{~km}^{2}\right.$ during dry and wet period, respectively). The classified images showed that the aquatic plants are abundant in the southern part of the lagoon where the lagoon water is fresh (IUCN and CEA, 2006).

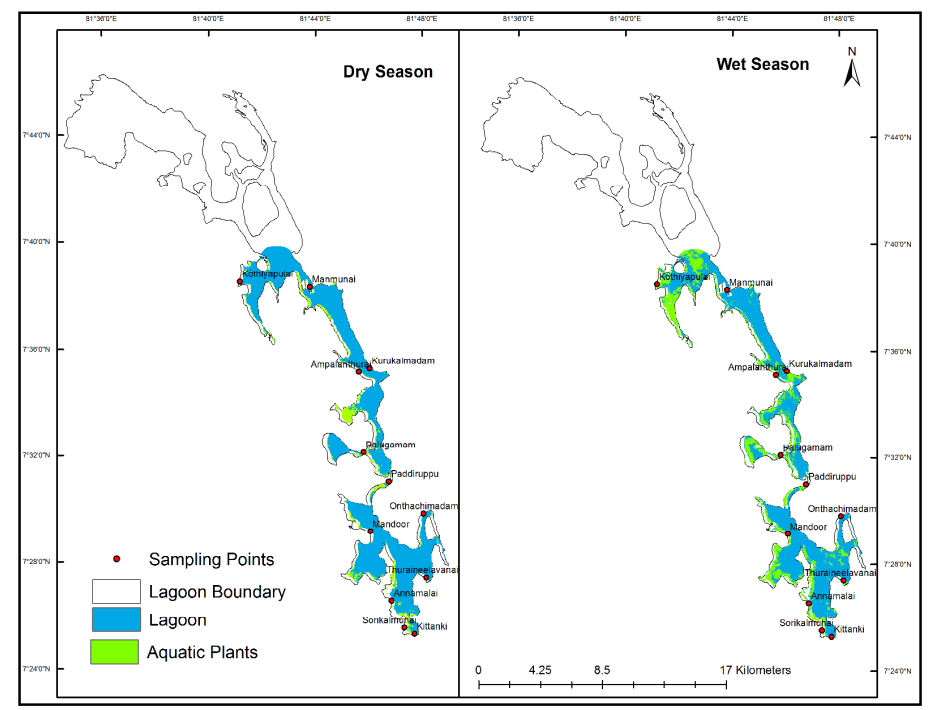

Figure 2. Distribution of floating aquatic plants in dry and wet seasons.

The LULC pattern of the buffer zone for 2017/2018 was classified into ten classes (Figure 3) according to the land cover distribution in the study area. The LULC classification revealed 
that most of the area surrounding the lagoon is covered by paddy lands and built up areas (including landfill and prawn farming) consisting 53\% and 39\% of the total, respectively. However, inland water bodies, natural vegetation, sand dunes, sea shore and mangrove/ marsh areas cover only a small portion of the land area. Further, Figure 3 shows that the cultivation of paddy lands around the lagoon area is seasonal. The paddy lands located in the southern part is cultivated during Yala season using fresh water in the lagoon while the paddy lands in the northern part are not cultivated due to high salinity condition in the lagoon (Sugirtharan et al., 2017). The paddy lands in the southern part are left as fallow in Maha season during the North East monsoonal period due to flooding. However, the paddy lands in the northern part of the lagoon are cultivated in Maha season as rainfed cultivation where the chance of flooding is less.

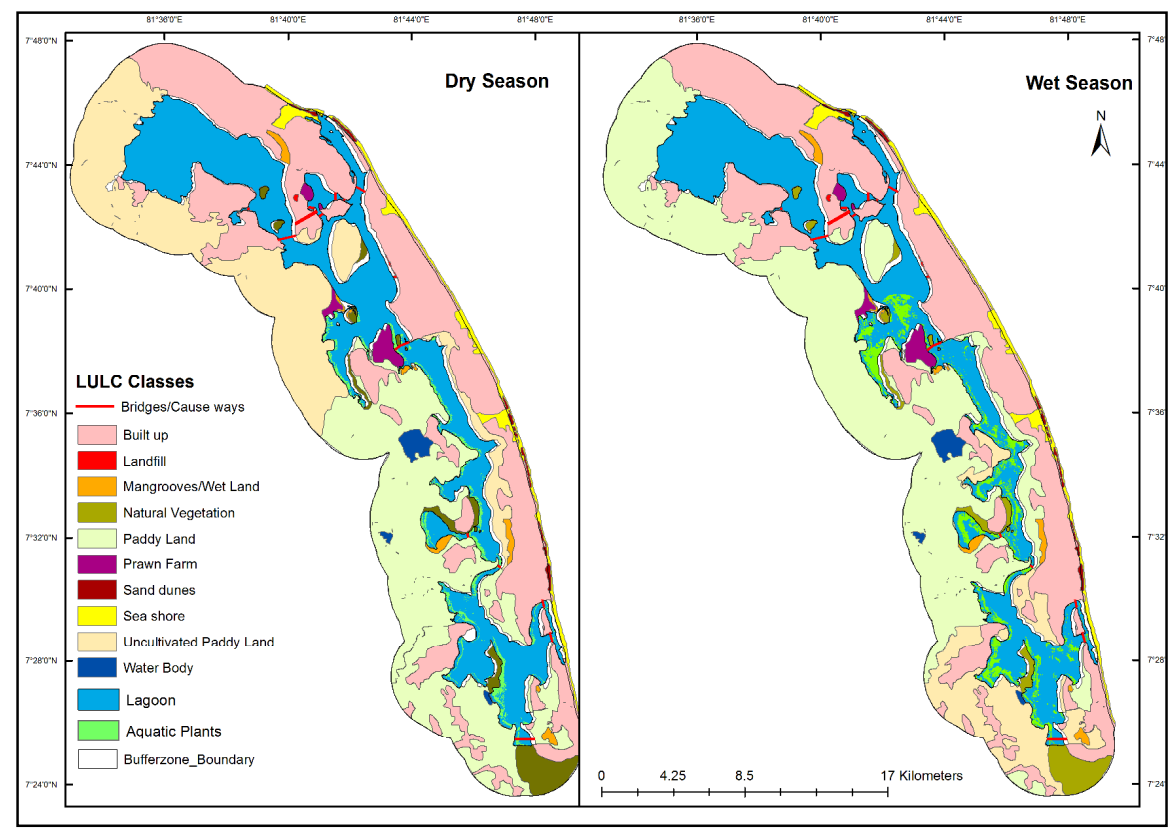

Figure 3. The LULC map of the study area in dry and wet seasons of 2017/2018.

The accuracy of the above FAPs and LULC maps were assessed using ground truth data and high resolution satellite imagery from Google Earth. The overall accuracy of the classification of FAPs map was $88.34 \%$ for May, $89.56 \%$ for June, $92.34 \%$ for July, $91.27 \%$ for September 2017 and $91.87 \%$ for January and $92.34 \%$ for February 2018 and the Kappa Coefficients were $0.84,0.89,0.92,0.91,0.91$ and 0.92 respectively. The overall accuracy and Kappa coefficient for the LULC maps of the Batticaloa lagoon were $90.47 \%$ and 0.90 and $92.47 \%$ and 0.92 for the dry and wet seasons, respectively.

\section{Field observations and estimation of biomass}

The growth of the aquatic plants showed a cyclic pattern from vegetative to flowering stage throughout the year. The plants are in vegetative stage during wet season (NE monsoonal period) and reach the flowering stage in the mid of dry season and return to the vegetative stage by the onset of NE monsoonal rain. Plants are subjected to decay due to salinity intrusion 
and water level reduction in places such as Manmuani, Kurukalmadam, Onthachimadam and Kothiyapuali during the dry season. The collected biomass of FAPs is mainly related to GBM and DBM in dry and wet season. The field GBM of the aquatic plants varied from 4.9 to $10.3 \mathrm{~kg} / \mathrm{m}^{2}$ and from 5.3 to $13.7 \mathrm{~kg} / \mathrm{m}^{2}$ during dry and wet season, respectively. Likewise, the DBM of the aquatic plants varied from 0.365 to $0.935 \mathrm{~kg} / \mathrm{m}^{2}$ and from 0.447 to $1.107 \mathrm{~kg} / \mathrm{m}^{2}$ during dry and wet season, respectively. Table 3 shows the average field biomass of aquatic plants in dry and wet season.

Table 3. Average field biomass of aquatic plants with mean standard error (MSE) in dry and wet season.

\begin{tabular}{llllll}
\hline \multirow{2}{*}{ No } & Location & \multicolumn{2}{c}{$\begin{array}{c}\text { Green Biomass } \pm \text { MSE } \\
\mathrm{kg} / \mathrm{m}^{2}\end{array}$} & \multicolumn{2}{c}{$\begin{array}{c}\text { Dry Biomass } \pm \text { MSE } \\
\mathrm{kg} / \mathrm{m}^{2}\end{array}$} \\
\cline { 3 - 6 } & & Dry & Wet & Dry & Wet \\
\hline 1 & Kothiyapulai & $5.37 \pm 2.11$ & $4.46 \pm 2.02$ & $0.365 \pm 0.18$ & $0.217 \pm 0.12$ \\
2 & Ampalanthurai & $6.27 \pm 0.75$ & $5.01 \pm 0.62$ & $0.559 \pm 0.08$ & $0.457 \pm 0.05$ \\
3 & Palugamam & $8.42 \pm 1.35$ & $6.31 \pm 1.12$ & $0.733 \pm 0.16$ & $0.443 \pm 0.20$ \\
4 & Paddiruppu & $8.68 \pm 1.00$ & $7.04 \pm 1.12$ & $0.715 \pm 0.08$ & $0.563 \pm 0.04$ \\
5 & Mandoor & $9.51 \pm 0.67$ & $13.51 \pm 1.11$ & $0.908 \pm 0.09$ & $1.091 \pm 0.23$ \\
6 & Annamalai & $8.45 \pm 0.71$ & $11.85 \pm 1.10$ & $0.721 \pm 0.05$ & $1.023 \pm 0.37$ \\
7 & Sorikalmunai & $8.50 \pm 0.94$ & $10.15 \pm 0.32$ & $0.714 \pm 0.07$ & $0.804 \pm 0.21$ \\
8 & Kittanki & $10.34 \pm 0.88$ & $13.74 \pm 1.52$ & $0.935 \pm 0.09$ & $1.107 \pm 0.47$ \\
9 & Thuraineelavanai & $7.76 \pm 0.87$ & $8.81 \pm 0.63$ & $0.883 \pm 0.14$ & $0.965 \pm 0.16$ \\
10 & Onthachimadam & $5.10 \pm 1.26$ & $12.79 \pm 1.78$ & $0.615 \pm 0.04$ & $1.085 \pm 0.07$ \\
11 & Kurukalmadam & $4.96 \pm 0.58$ & $3.59 \pm 0.47$ & $0.644 \pm 0.13$ & $0.268 \pm 0.08$ \\
12 & Manmunai & $7.15 \pm 0.57$ & $6.43 \pm 0.42$ & $0.501 \pm 0.02$ & $0.421 \pm 0.02$ \\
\hline
\end{tabular}

The highest values of GBM were obtained from Kittanki and the lowest from Kurukalmadam and the highest values of DBM were obtained from Kittanki and the lowest from Kothiyapulai in both seasons. LULC in the buffer zone of Batticaloa lagoon (Figure 3) depicts that Kittanki is surrounded by paddy lands and the cultivation is solely depends on lagoon water in dry season. Therefore, there is a high possibility of nitrate and phosphate enrichment in the lagoon water due to application of organic and inorganic fertilizers in farm lands (Sugirtharan et al., 2017). Nutrient enrichment in water enhances the growth and the biomass of aquatic plants in the lagoon shore. The location is also highly exposed to lagoon flooding in the wet season where the possibility of nutrient accumulation is high due to surface runoff from adjacent land uses (Paddy and Built ups). In contrast, Kurukalmadam and Kothiyapulai are less affected with human interventions and surrounded by natural mangrove systems. These points also act as salinity transition zone and therefore, nutrient availability to plant growth is limited and the aquatic plants do not reach their maturity stage in the growth cycle due to increasing salinity.

\section{Development of relationships between satellite derived indices and field measured biomass for biomass estimation}

Linear and Exponential regression models were developed using relationships between Band ratios and indices and the field measured biomass. The in situ GBM and DBM in both seasons 
correlated weakly $(\mathrm{r}=0.1-0.2)$ to $\mathrm{S} 2 \mathrm{~A}$ band ratios and indices of $\mathrm{B} 2 / \mathrm{B} 3, \mathrm{~B} 2 / \mathrm{B} 4, \mathrm{~B} 2 / \mathrm{B} 8$, $\mathrm{B} 3 / \mathrm{B} 8$, GNDVI and NGRDI and moderately $(\mathrm{r}=0.3-0.5)$ to $\mathrm{S} 2 \mathrm{~A}$ bands B2/B8, B3/B8, B3/B4, B4/B3, B8/B4, B3-B2, B3-B4, (B2-B4)/(B2+B4) and NDVI. The Field values were not correlated with B3-B2, B3-B4, (B2+B3)/2, $(\mathrm{B} 2+\mathrm{B} 4) / 2,(\mathrm{~B} 3+\mathrm{B} 4) / 2$ and $(\mathrm{B} 2-\mathrm{B} 3) / \mathrm{B} 3$ ratios. The correlation was strong positive for the ratios and indices of $\mathrm{B} 3 / \mathrm{B} 2, \mathrm{~B} 3 / \mathrm{B} 4, \mathrm{~B} 8 / \mathrm{B} 4$, NDREI, NDREI_narrow. Table 4 summarizes the best fit models obtained to develop the biomass maps for the FAPs.

Table 4. Regression models obtained from the RS ratios and field BM.

\begin{tabular}{|c|c|c|c|c|}
\hline $\begin{array}{l}\text { Biomass } \\
\text { type }\end{array}$ & Band Ratio & Bands & Best fit model & $\mathbf{r}^{2}$ \\
\hline \multirow[t]{3}{*}{$\begin{array}{l}\text { GBM_ } \\
\text { Dry }\end{array}$} & $\mathrm{B} 3 / \mathrm{B} 2$ & Green/Blue & $\begin{array}{l}\text { GBM_Dry = } \\
32.624 * \text { B3/B2 }-24.053\end{array}$ & 0.77 \\
\hline & $\mathrm{B} 3 / \mathrm{B} 4$ & Green/Red & $\begin{array}{l}\text { GBM_Dry }= \\
4.7417 * \text { B3/B4 }+3.3698\end{array}$ & 0.76 \\
\hline & $\begin{array}{l}\text { NDREI }(\mathrm{B} 8- \\
\mathrm{B} 5) /(\mathrm{B} 8+\mathrm{B} 5)\end{array}$ & $\begin{array}{l}\text { (NIR-Red } \\
\text { edge/NIR+Red } \\
\text { edge) }\end{array}$ & $\begin{array}{l}\text { GBM_Dry }= \\
25.927 * \text { NDREI }+5.0785\end{array}$ & 0.78 \\
\hline \multirow[t]{4}{*}{$\begin{array}{l}\text { GBM_ } \\
\text { Wet }\end{array}$} & $\mathrm{B} 3 / \mathrm{B} 2$ & Green/Blue & $\begin{array}{l}\text { GBM_Wet }= \\
37.668 * \text { B3/B2 }-23.987\end{array}$ & 0.62 \\
\hline & $\mathrm{B} 8 / \mathrm{B} 4$ & NIR/Red & $\begin{array}{l}\text { GBM_Wet }= \\
1.9239 * \text { B8/B4+3.7561 }\end{array}$ & 0.68 \\
\hline & $\begin{array}{l}\text { NDREI (B8- } \\
\text { B5)/(B8+B5) }\end{array}$ & $\begin{array}{l}\text { (NIR-Red } \\
\text { edge/NIR+Red } \\
\text { edge) }\end{array}$ & $\begin{array}{l}\text { GBM_Wet }= \\
0.0048^{*} \text { NDREI }+0.0236\end{array}$ & 0.76 \\
\hline & $\begin{array}{l}\text { NDREI_narrow } \\
\text { (B8a- } \\
\text { B5)/(B8a+B5) }\end{array}$ & $\begin{array}{l}\text { (NIR narrow- } \\
\text { Red edge/NIR } \\
\text { narrow+Red } \\
\text { edge) }\end{array}$ & $\begin{array}{l}\text { GBM_Wet }= \\
13.05^{*} \text { NDREI_narrow }+ \\
5.2065\end{array}$ & 0.70 \\
\hline \multirow[t]{2}{*}{$\begin{array}{l}\text { DBM }_{-} \\
\text {Dry }\end{array}$} & $\mathrm{B} 3 / \mathrm{B} 4$ & Green/Red & $\begin{array}{l}\text { DBM_Dry }= \\
0.4777 * \mathrm{~B} 3 / \mathrm{B} 4+0.2374\end{array}$ & 0.73 \\
\hline & $\begin{array}{l}\text { NDREI }(\mathrm{B} 8- \\
\mathrm{B} 5) /(\mathrm{B} 8+\mathrm{B} 5)\end{array}$ & $\begin{array}{l}\text { (NIR-Red } \\
\text { edge/NIR+Red } \\
\text { edge })\end{array}$ & $\begin{array}{l}\text { DBM_Dry }= \\
121.17 * \text { NDREI }+1.4568\end{array}$ & 0.73 \\
\hline \multirow[t]{4}{*}{$\begin{array}{l}\text { DBM } \\
\text { Wet }\end{array}$} & $\mathrm{B} 3 / \mathrm{B} 2$ & Green/Blue & $\begin{array}{l}\text { DBM_Wet }= \\
3.3291 * \text { B3/B2 -2.1774 }\end{array}$ & 0.70 \\
\hline & $\mathrm{B} 8 / \mathrm{B} 4$ & NIR/Red & $\begin{array}{l}\text { DBM_Wet }= \\
0.1667 * \mathrm{~B} 8 / \mathrm{B} 4+0.2835\end{array}$ & 0.72 \\
\hline & $\begin{array}{l}\text { NDREI }(\mathrm{B} 8- \\
\mathrm{B} 5) /(\mathrm{B} 8+\mathrm{B} 5)\end{array}$ & $\begin{array}{l}\text { (NIR-Red } \\
\text { edge/NIR+Red } \\
\text { edge })\end{array}$ & $\begin{array}{l}\text { DBM_Wet }= \\
10.035^{*} \text { NDREI+ } 0.1132\end{array}$ & 0.72 \\
\hline & $\begin{array}{l}\text { NDREI_narrow } \\
\text { (B8a- } \\
\text { B5)/(B8a+B5) }\end{array}$ & $\begin{array}{l}\text { (NIR narrow- } \\
\text { Red edge/NIR } \\
\text { narrow+Red } \\
\text { edge) }\end{array}$ & $\begin{array}{l}\text { DBM_Wet }= \\
1.0178 * \text { NDREI_narrow }+ \\
0.442\end{array}$ & 0.61 \\
\hline
\end{tabular}

Linear relationships are more prominent than exponential relationships between field measured biomass and remote sensing indices and band ratios. This can be supported by the study of Ha et al. (2017) and Toming et al. (2016) where the NIR, NIR narrow, green, red and 
red edge bands $\left(r^{2}=0.68\right)$ gave a significant impact in chlorophyll estimation in the tropical aquatic systems. Figure 4 shows the developed regression models between in situ BM and S2A band ratios with a strong correlation in dry season.

Among tested remote sensed algorithms, two single band ratios (B3/B2 and B3/B4) and one vegetation index (NDREI) showed strong positive correlation with the in situ data $\left(\mathrm{r}^{2}=0.77\right.$, 0.76 and 0.78$)$ for the GBM and B3/B4 and NDREI for DBM $\left(\mathrm{r}^{2}=0.73\right.$ and 0.71$)$, respectively in the dry season. Studies show that the MSI on S2A has a high potential for monitoring chlorophyll content in coastal and inland waters due to its red-edge band (band 5:705 nm) and red band (band 4: $665 \mathrm{~nm}$ ) in the Chl-a absorption (Toming et al., 2016) and Cho et al. (2017) obtained better results from using empirical relationships between chlorophyll a and reflectance in the "red edge" of the visible spectrum.
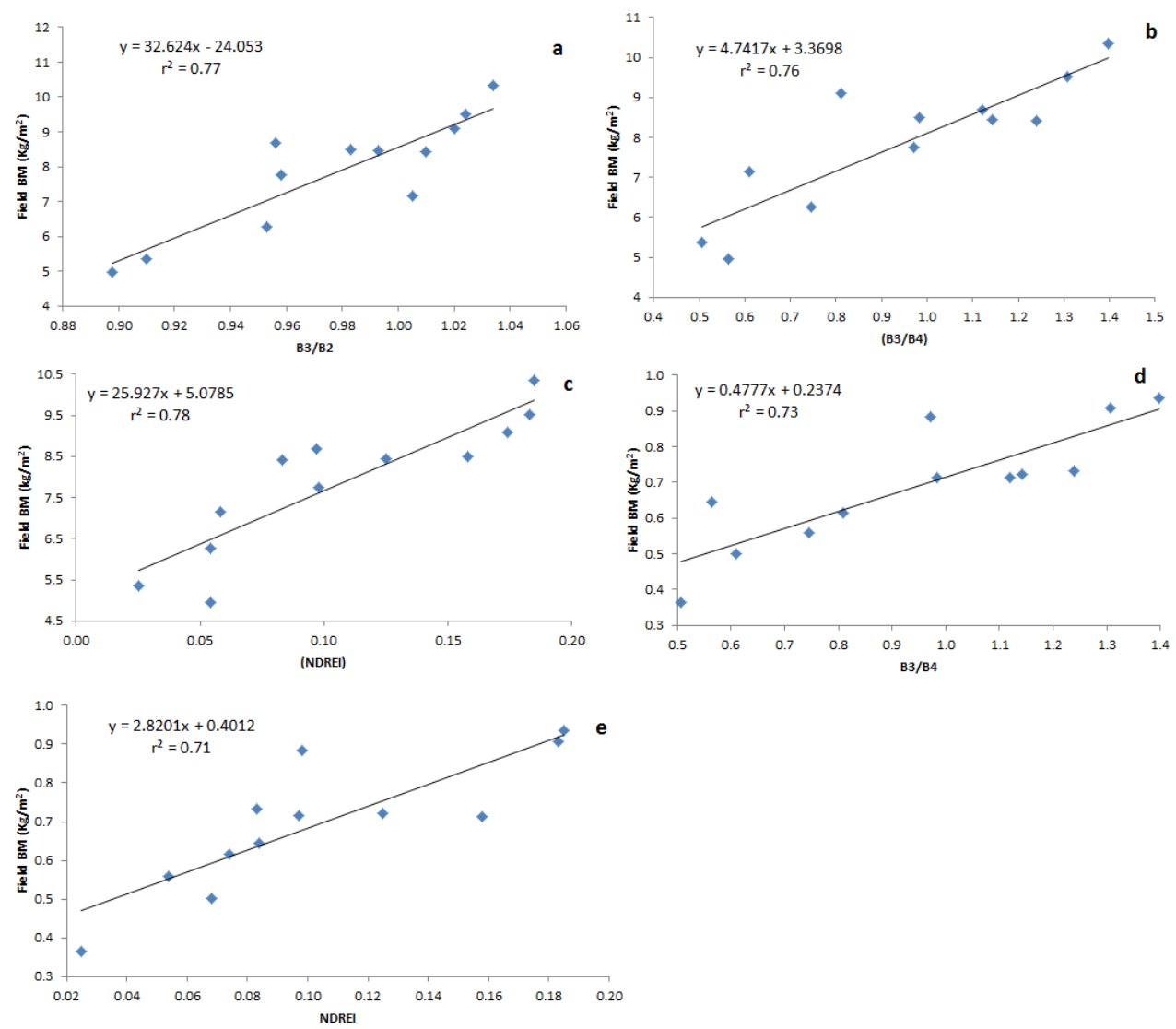

Figure 4. Regression relationships between dry season green biomass and (a) B3/B2, (b) B3/B4 (c) NDREI, dry biomass and (d) B3/B4 and (e) NDREI.

Figure 5 shows the developed regression models between in situ BM and S2A band ratios with strong correlation in wet season. The band ratios (B3/B2 and B8/B4) and vegetation indices (NDREI and NDREI_Narrow) show strong correlation with the GBM $\left(\mathrm{r}^{2}=0.62,0.67\right.$, $0.73,0.70)$ respectively and with the DBM $\left(\mathrm{r}^{2}=0.70,0.72,0.72,0.61\right)$ respectively for wet season. Similar observations were obtained in Ha et al. (2017) where, the narrow region of 
the NIR band gives more significant values compare to the spectral reflectance of the visible and NIR regions in estimating chlorophyll of aquatic vegetation in wet season. The standard error estimation for the above strongly correlated band ratios and indices were used to select the best ratio to estimate biomass and to produce maps for the aquatic plants in the study area. According to the Mean Standard Error values (MSE), NDREI and B8/B4 ratios showed lowest values of $13 \%$ and $6 \%$ to the GBM in dry season and wet season, respectively. While, ratios B3/B4 and NDREI_narrow show the lowest values of $12 \%$ and $6.5 \%$ to the DBM in dry and wet season, respectively. Studies show that the ratios with small MSE, ranges between $7.5 \%$ and $15 \%$ of in situ data can be used for the remote sensed based estimation in the water bodies (Ha et al., 2017).
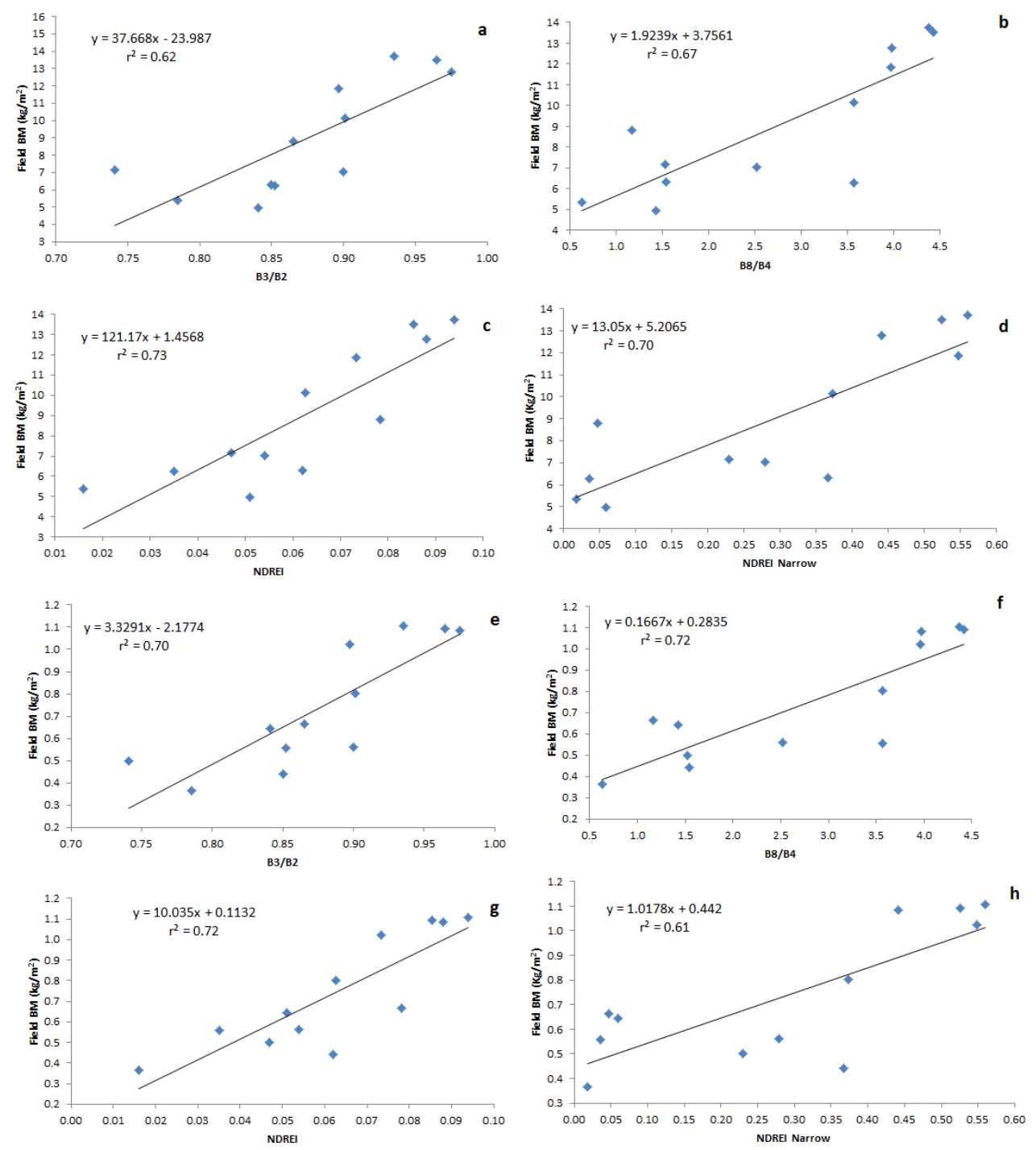

Figure 5. Regression models of Green and Dry biomass in wet season using B3/B2, B8/B4, NDREI and NDREI_Narrow 


\section{Development of biomass maps of FAPs}

Figure 6 shows the distribution of estimated GBM of aquatic plants in Batticaloa Lagoon over Dry and Wet seasons. The GBM of the aquatic plants in the Lagoon was mapped using the model equation obtained from NDREI in dry season and B8/B4 in wet season. The biomass was ranging from $5.9 \mathrm{~kg} / \mathrm{m}^{2}$ (in May 2017) to $8.3 \mathrm{~kg} / \mathrm{m}^{2}$ (in September 2017) in the dry period and from $7.7 \mathrm{~kg} / \mathrm{m}^{2}$ (in January 2017) to $10.3 \mathrm{~kg} / \mathrm{m}^{2}$ (in February 2018) in the wet season.

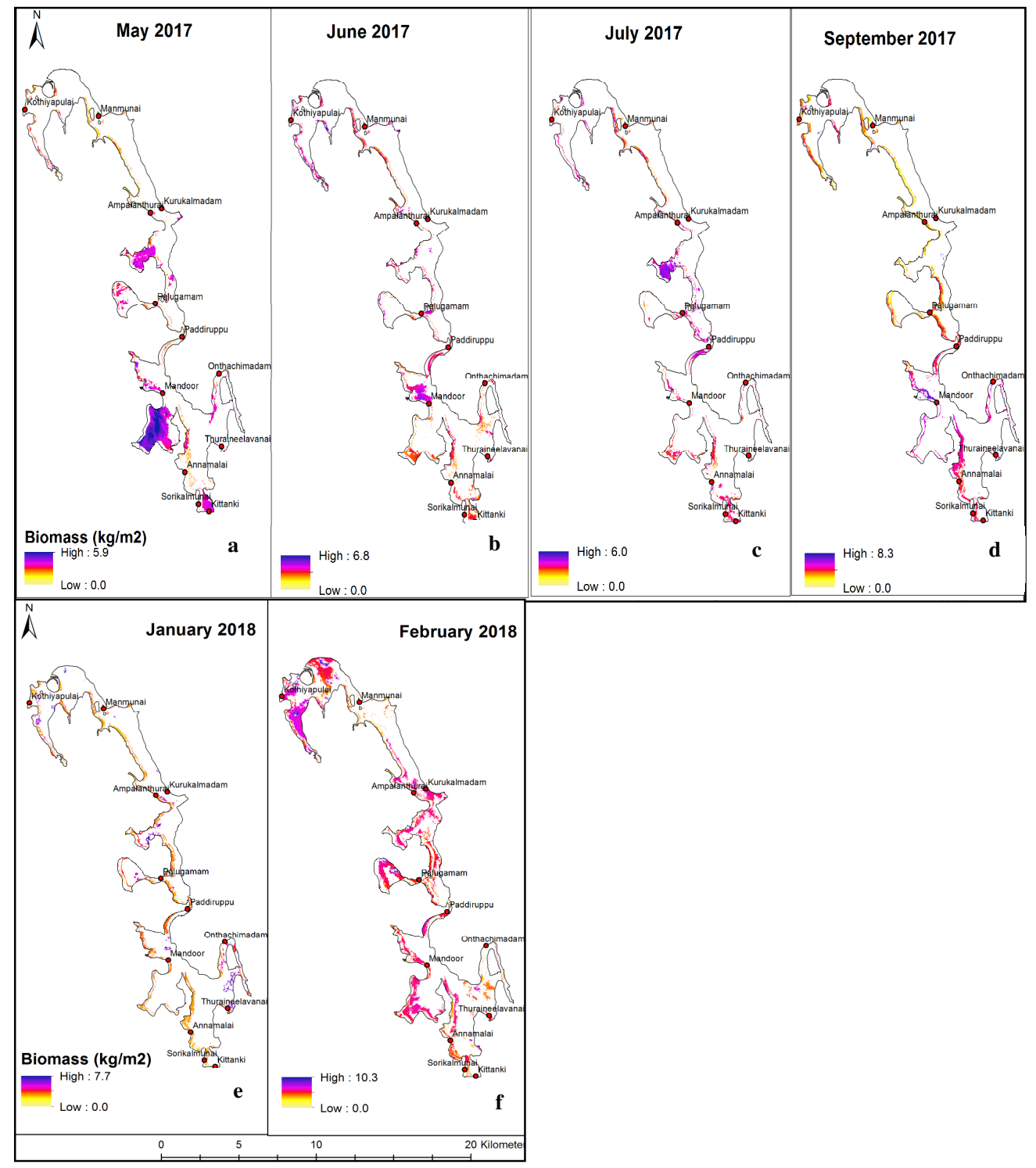

Figure 6. Estimated Green Biomass distribution of FAPs over Batticaloa Lagoon. 
The GBM showed high values in fully matured vegetative stage (February) and flowering stage (August to September) and lower at emergent stage (May). Similar pattern was observed in field measured GBM where it was low in the months of pre monsoonal period (March to April), increased to peak in mid to late dry period (June to September), gradually decreased to a low level during second inter monsoonal period (October to November) and then increased again in the NE monsoonal season which lasts up to the end of the wet season (December to February).

Spectral reflectance of aquatic plants greatly depends on the morphological features and growth stage (Cho et al., 2008). According to the study of Cho et al. (2008) and Villa et al. (2017) spectral reflectance varies according to the vegetation stage in water hyacinth (Eichhornia crassipes). Healthy water hyacinth shows green reflectance peak at around 557 $\mathrm{nm}$, red absorption near 640-670 $\mathrm{nm}$ and the NIR peak near 840-880 $\mathrm{nm}$. However, when the plants are at their flowering stage, the spectral reflectance pattern shows the transition of NIR band to red edge reflectance. This is obvious that, the NDREI derived from NIR and red edge bands to estimate GBM were highly correlated with in situ BM during dry season where the plants are at their flowering stage. In contrast, Red and NIR band ratio shows high correlation with in situ BM in the wet season (Figure 6) where the plants are in vegetative stage.

Figure 7 presents the temporal changes in the estimated DBM of aquatic plants distribution over Batticaloa Lagoon. The spatial variation of estimated DBM shows a similar pattern to the GBM. The DBM of the aquatic plants in the lagoon ranged from $407.8 \mathrm{~g} / \mathrm{m}^{2}$ (in May 2017) to $841.17 \mathrm{~g} / \mathrm{m}^{2}$ (in September 2017) in the dry period and from $516.4 \mathrm{~g} / \mathrm{m}^{2}$ (in January 2017) to $942.8 \mathrm{~g} / \mathrm{m}^{2}$ (in February 2018). The nutrient enrichment in water and accumulation of nutrients in plant bodies help to increase the DBM in plants (Villa et al., 2017). The DBM also varies according to the seasonal pattern since discharge of nutrients from the paddy lands in the buffer zone and the effluent of rice mills impact the growth and distribution of plants in the lagoon system. The LULC distribution in the buffer zone of the lagoon (Figure 3) revealed that lagoon shore area is highly occupied with paddy cultivation. The rice mills too can be noticed in the buffer zone (Thuraineelavanai), where the lagoon water can be polluted by agricultural wastes (Nitrate and phosphate) and rice mill effluents (Pradhan and Sahu, 2004). According to Figure 6 the distribution of biomass is high in places such as Kittanki, Mandoor, Annamalai and Palugamam which are exposed to agricultural pollution and Thuraineelavanai which has a threat of contamination with rice mill effluent.

Seasonal distribution of biomass reveals that there is a significant difference between average GBM in dry and wet season and average DBM in dry and wet season $(\mathrm{p}<0.05)$. This shows that the biomass content of the aquatic plants depends on the seasonal availability of the nutrient contents in the lagoon water. This distribution can be seen clearly in estimated BM maps from the S2A scenes (Figure 6 and 7) developed for dry season (May to September) and wet season (January and February). High values of BM in dry season presence in the areas close proximity to the paddy lands such as Mandoor, Thuraineelavanai, Annamalai and Palugamam which are exposed to agricultural pollution due to cultivation practices. High values of estimated biomass can be seen in places such as Ampalanthurai, Onthachimadam and Paddiruppu in the wet season. The strong water exchange with nutrients to the northern part of the lagoon due to flooding during NE monsoonal period causes to increase GBM and DBM in the upper part of the lagoon. Similar observations were identified in the study of 
Toming et al. (2016) where the chlorophyll content changes over the season due to water exchanges in the lake and highly impact by the nutrient availability in the lake

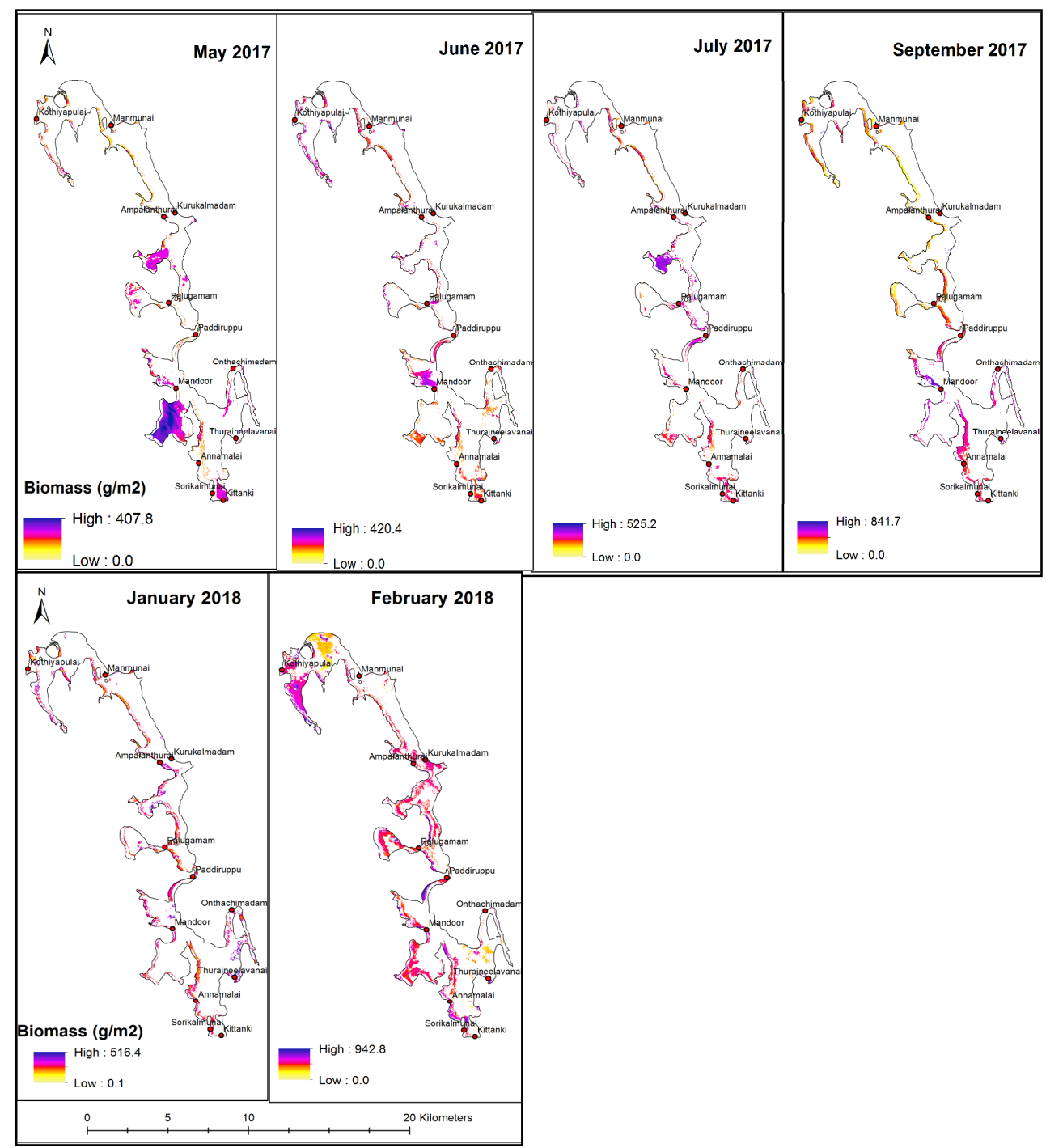

Figure 7. Dry Biomass distribution of FAPs over Batticaloa Lagoon. 


\section{CONCLUSIONS}

Band ratios, B8/B4 and B3/B4 and vegetation indices NDREI and NDREI_Narrow were the most suitable in GBM and DBM assessment in dry and wet season in Batticaloa lagoon. The estimated GBM of the aquatic plants using NDREI index is ranging from 5.9 to $8.3 \mathrm{~kg} / \mathrm{m}^{2}$ in the dry period and using B8/B4 ratio ranged from 7.7 to $10.3 \mathrm{~kg} / \mathrm{m}^{2}$ in wet period. The DBM of the aquatic plants in the Lagoon ranged from 407.8 to $841.17 \mathrm{~g} / \mathrm{m}^{2}$ in the dry period and from 516.4 to $942.8 \mathrm{~g} / \mathrm{m}^{2}$. The study identified the potential of S2A MSI images for monitoring the biomass of floating aquatic plants in the coastal aquatic system.

\section{ACKNOWLEDWGEMENT}

The authors sincerely acknowledge the financial support provided by the Postgraduate Institute of Agriculture, University of Peradeniya, Sri Lanka under the Research Facilitation Fund to carry out this study

\section{REFERENCES}

Ayanlade, A. (2017). Remote sensing vegetation dynamics analytical methods: A review of vegetation indices techniques. GEOINFORMATICA POLONICA. 16, 7-17 [on line]. [Accessed on 03.02.2018]. Available at https://www.ejournals.eu/pliki/art/9961/pdf doi: $10.4467 / 21995923$ GP.17.001.7188

Cho, H.J., Kirui, P. and Natarajan, H. (2008). Test of Multi-spectral Vegetation Index for Floating and Canopy-forming Submerged Vegetation. Int. J. Environ. Res. Public Health. 5(5), 477-483 [on line]. [Accessed on 21.03.2018]. Available at http://www.mdpi.com/1660$\underline{4601 / 5 / 5 / 477}$

Downing, J. A. and Anderson, R. (1985). Estimating the standing biomass of aquatic macrophytes. Can. J. Fish. Aquat. Sco. 42, 1860-1869. [on line]. [Accessed on 05.04.2017]. Available

at https:// www.public.iastate.edu/ downing/.../1985\%20CJFAS\%20Estimating\%20the\%20standing biomass.pdf

Ha, N.T.T., Thao, N. T. P., Koike., K. and Nhuan, M. T. (2017). Selecting the Best Band Ratio to Estimate Chlorophyll-a Concentration in a Tropical Freshwater Lake Using Sentinel 2A Images from a Case Study of Lake Ba Be (Northern Vietnam). ISPRS Int. J. Geo-Inf. 6, 290305 [on line]. [Accessed on 02.03.2018]. Available at https://www.mdpi.com/journal/ijgi doi:10.3390/ijgi6090290 https://sentinel.esa.int/web/sentinel/missions/sentinel-2. Earth Space Agency (ESA) (2009). Sentinel-2 - Missions - Sentinel Online [on line]. [Accessed on 24.01.2017].

IUCN Sri Lanka and the Central Environmental Authority. (2006). National Wetland Directory of Sri Lanka, Colombo, Sri Lanka.

Jensen, J. R. (2004). Remote sensing of the environment: An earth resource perspective ( $2^{\text {nd }}$ edn). Pearson Education, Inc, pp.361-364. 
JUGAS Ltd. (2010). A Participatory Assessment of the Dynamics, Seasonal variation and Current Status of Fishery in Batticaloa Lagoon. Final Draft Report. p. 126.

Madsen, J. D. (1993) Biomass Techniques for Monitoring and Assessing Control of Aquatic Vegetation, Lake and Reserv. Manage. 7(2), 141-154. [on line]. [Accessed on 05.04.2017]. Available at http://www.tandfonline.com/loi/ulrm20 doi: $10.1080 / 07438149309354266$

Pradhan, A and S. K. Sahu (2004). Process details and effluent characteristics of a rice mill in the Sambalpur district of Orissa. Journal of Industrial Pollution Control 20 (1), 111 -124 [on line].[Accessed on 28.12.2017]. Available at https://www.researchgate.net/publication/267712189

Punyawardena, B. V. R. (2010). Climate of the Dry zone of Sri Lanka, In: Mapa, R. B., Somasiri, S. and Dassanayake, A. R. (Eds.) Soils of the Dry Zone of Sri Lanka. pp: 9-24. Soil Science Society of Sri Lanka.

Rouse, J.W., Hass, R.H., Schell, J. A. and Deering, D. W. (1974). Monitoring Vegetation systems in the Great Plains with ERTS. Proceedings, Third Earth Resources Technology Satellite-1 Symposium, Greenbelt: NASA SP-351, 3010-3014, In: Jensen, J. R. (2004). Remote sensing of the environment: An earth resource perspective ( $2^{\text {nd }}$ Edn). Pearson Education, Inc, pp.386-387.

Sobadini, K. (2006). Aquatic weeds in Sri Lanka, In: Darshani, S. (Ed.) Biodiversity, Water Resources [on line]. [Accessed on 10.05.2017]. Available at http://environmentlanka.com/blog/2006/aquatic-weeds-in-sri-lanka/

Sugirtharan,M., Pathmarajah, S. and Mowjood, M.I.M. (2017). Spatial and Temporal Dynamics of Water Quality in Batticaloa Lagoon in Sri Lanka. Tropical Agricultural Research Vol. 28 (3): 281- 397

Toming, K., Kutser, T., Laas, A., Sepp, M., Paavel., B. and Nõges,T. (2016). First experiences in mapping lake water quality parameters with Sentinel-2 MSI Imagery. Remote Sens. 8, 640654 [on line]. [Accessed on 21.03.2018]. Available at http://www.mdpi.com/journal/remotesensing/2072-4292/8/8/640 doi:10.3390/rs8080640

Villa, P., Pinardi, M., TóTh, V., HunTer, P., BolPagni, R. and Bresciani, M. (2017). Remote sensing of macrophyte morphological traits: Implications for the management of shallow lakes. J. Limnol. 76(s1), 109-126 [on line]. [Accessed on 28.12.2017]. Available at https://doi.org/10.4081/jlimnol.2017.1629 doi: 10.4081/jlimnol.2017.1629 